Article

\title{
Vernonia calvoana Shows Promise towards the Treatment of Ovarian Cancer
}

\author{
Ariane T. Mbemi ${ }^{1}$, Jennifer N. Sims ${ }^{2}$, Clement G. Yedjou ${ }^{1,3, * \mathbb{C}}$, Felicite K. Noubissi ${ }^{4}{ }^{(\mathbb{D}}$, \\ Christian R. Gomez ${ }^{5}$ and Paul B. Tchounwou ${ }^{4, *} * \mathbb{1}$
}

1 Natural Chemotherapeutics Research Laboratory, NIH/NIMHD RCMI-Center for Environmental Health, College of Science, Engineering and Technology, Jackson State University, 1400 Lynch Street, Jackson, MS 39217, USA; ariane.t.mbemi@jsums.edu

2 School of Public Health, Jackson State University, Jackson Medical Mall-Thad Cochran Center, 350 West Woodrow Wilson Avenue, Jackson, MS 39213, USA; jennifer.n.sims@jsums.edu

3 Department of Biological Sciences, College of Science and Technology, Florida Agricultural and Mechanical University, 1610 S. Martin Luther King Blvd, Tallahassee, FL 32307, USA

4 Department of Biology, College of Science, Engineering and Technology, Jackson State University, 1400 Lynch Street, Jackson, MS 39217, USA; felicite.noubissi_kamdem@jsums.edu

5 Departments of Pathology and Radiation Oncology, Center for Clinical and Translational Science, University of Mississippi Medical Center, 2500 N. State St., Jackson, MS 39216, USA; CRGomez@umc.edu

* Correspondence: clement.yedjou@famu.edu (C.G.Y.); paul.b.tchounwou@jsums.edu (P.B.T.); Tel.: +1-850-599-3908 (C.G.Y.); +1-601-979-2095 (P.B.T.); Fax: +1-601-979-5853 (P.B.T.)

Received: 26 May 2020; Accepted: 15 June 2020; Published: 22 June 2020

\begin{abstract}
The treatment for ovarian cancers includes chemotherapies which use drugs such as cisplatin, paclitaxel, carboplatin, platinum, taxanes, or their combination, and other molecular target therapies. However, these current therapies are often accompanied with side effects. Vernonia calvoana (VC) is a valuable edible medicinal plant that is widespread in West Africa. In vitro data in our lab demonstrated that VC crude extract inhibits human ovarian cancer cells in a dose-dependent manner, suggesting its antitumor activity. From the VC crude extract, we have generated 10 fractions and VC fraction 7 (F7) appears to show the highest antitumor activity towards ovarian cancer cells. However, the mechanisms by which VC F7 exerts its antitumor activity in cancer cells remain largely unknown. We hypothesized that VC F7 inhibits cell proliferation and induces DNA damage and cell cycle arrest in ovarian cells through oxidative stress. To test our hypothesis, we extracted and fractionated VC leaves. The effects of VC F7 were tested in OVCAR-3 cells. Viability was assessed by the means of MTS assay. Cell morphology was analyzed by acridine orange and propidium iodide $(\mathrm{AO} / \mathrm{PI})$ dye using a fluorescent microscope. Oxidative stress biomarkers were evaluated by the means of lipid peroxidation, catalase, and glutathione peroxidase assays, respectively. The degree of DNA damage was assessed by comet assay. Cell cycle distribution was assessed by flow cytometry. Data generated from the MTS assay demonstrated that VC F7 inhibits the growth of OVCAR-3 cells in a dose-dependent manner, showing a gradual increase in the loss of viability in VC F7-treated cells. Data obtained from the AO/PI dye assessment revealed morphological alterations and exhibited characteristics such as loss of cellular membrane integrity, cell shrinkage, cell membrane damage, organelle breakdown, and detachment from the culture plate. We observed a significant increase $(p<0.05)$ in the levels of malondialdhyde (MDA) production in treated cells compared to the control. A gradual decrease in both catalase and glutathione peroxidase activities were observed in the treated cells compared to the control. Data obtained from the comet assay showed a significant increase $(p<0.05)$ in the percentages of DNA cleavage and comet tail length. The results of the flow cytometry analysis indicated VC F7 treatment caused cell cycle arrest at the S-phase checkpoint. Taken together, our results demonstrate that VC F7 exerts its anticancer activity by inhibiting cell proliferation, inducing DNA damage, and causing cell cycle arrest through oxidative stress in OVAR-3
\end{abstract}


cells. This finding suggests that VC F7 may be a potential alternative dietary agent for the prevention and/or treatment of ovarian cancer.

Keywords: Vernonia calvoana; OVCAR-3 cells; cell viability; oxidative stress; DNA damage; cell cycle

\section{Introduction}

Ovarian cancer is classified as the leading cause of death in gynecological cancer among women [1,2]. Family history of breast or ovarian cancer is the strongest risk factor for developing ovarian cancer [3]. The American College of Obstetricians and Gynecologists and the Society of Gynecologic Oncology recommend that females with BRCA1 and/or BRCA2 mutations should consider the use of oral contraceptives which may reduce the risk of developing ovarian cancer by approximately $50 \%$ among high-risk females [4-7]. Due to the location of the ovaries in the female reproductive system, ovarian cancer is considered a "silent killer", and over $70 \%$ of cases are diagnosed at the advanced stages [8,9]. Last year, there was an approximate of 22,240 new cases of ovarian cancer diagnosed and about 14,070 ovarian cancer deaths in North America [10]. Ovarian cancer accounts for about $2.5 \%$ of all malignancies among women worldwide. However, $5 \%$ of female cancer deaths are attributed to low survival rates, largely due to late stage diagnoses [11].

The current first line of treatment for ovarian cancers are chemotherapies which use drugs such as cisplatin, paclitaxel, carboplatin, platinum, taxanes, or their combination, and other molecular target therapies [10,12]. However, these therapies for ovarian cancer are usually accompanied with side effects such as hair loss, loss of appetite, and infertility [13]. About $70 \%$ of the patients diagnosed with recurring ovarian cancer will die within five years of their diagnosis [14]. Medicinal plants are gaining special consideration and value in the discovery for ovarian cancer drugs. Vernonia calvoana (VC), commonly called sweet bitter leaf in English, is an Asteraceae that has been widely consumed as vegetable and used to treat diseases such as diabetes, measles, tuberculosis, hyperlipidemia, and women infertility in many Africa countries $[15,16]$. Scientific reports indicated that the leaves of VC contain phytochemicals such as flavonoids, which are good antioxidants [17-19]. In addition, scientific reports indicated that VC possesses the hepatoprotective effect and hypolipidemic and antidiabetic activities [20]. Testing the medicinal property of Vernonia amygdalina, a member of the same genus as Vernonia calvoana, we demonstrated in our lab that this medicinal plant possesses anticancer activity potential against human breast cancer cells [21,22]. Other Vernonia species including Vernonia divaricate and Vernonia amygdalina act as potential anticancer agents that inhibit the proliferation of HL-60 cells, MCF-7 cells and PC-3 cells $[23,24]$. Although VC have been used traditionally to treat many illnesses, the mechanisms by which it exerts its antitumor activity in OVCAR-3 cells remain largely unknown. Therefore, our objective was to test the therapeutic efficacy of the most bioactive compound of VC against ovarian cancer.

\section{Results}

\subsection{Antiproliferative Effect}

The results showed that VC F7 treatment significantly decreased the viability of OVCAR-3 cells (Figure 1). As seen in Figure 1, the percentages of viability of OVCAR-3 cells treated with VC F7 upon $48 \mathrm{~h}$ were $100 \pm 5.73 \%, 63 \pm 2.78 \%, 43 \pm 1.27 \%, 31 \pm 0.92 \%$ in $0,8,16,32 \mu \mathrm{g} / \mathrm{mL}$, respectively. These results revealed that the OVCAR-3 cells are more sensitive to VC F7 treatment with an estimated inhibition dose $\left(\mathrm{IC}_{50}\right)$ equal to $18.56 \mu \mathrm{g} / \mathrm{mL}$. These data showed that VC F7 caused growth arrest of OVCAR-3 cells, suggesting its potential as an anticancer agent. 


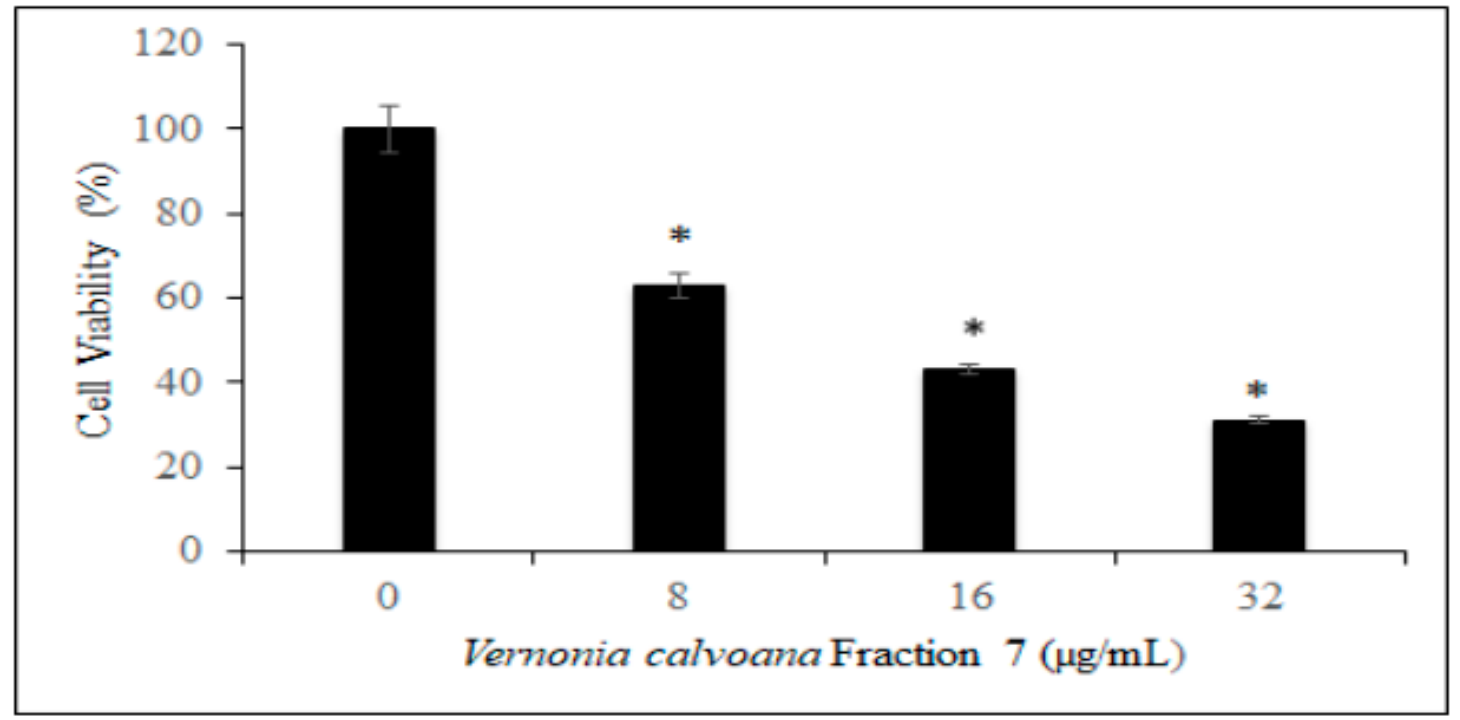

Figure 1. Antiproliferative effect of Vernonia calvoana fraction 7 (VCF7) on OVCAR-3 cells. The OVCAR-3 cells were treated with different doses of VC F7 for $48 \mathrm{~h}$. The cell viability was measured by MTS assay as described in the Materials and Methods section. Each data point represents the mean value and standard deviation $(n=3) .{ }^{*}$ Asterisks denote a statistically significant difference $(p<0.05)$ between the control and the treated groups according to the ANOVA Dunnett test.

\subsection{Morphological Changes}

To confirm the antiproliferative effect of VCF7 on OVCAR-3 cells, we examined the cell morphology by acridine orange/propidium iodide (AO/PI) double staining assay. We observed that VC F7 inhibits the proliferation of OVCAR-3 cells in a dose-dependent manner (Figure 2). As seen in Figure 2, there is a strong dose-response relationship in regard to VC F7 treatment, showing a significant increase in the percentage of dead cells compared to the percentage of live cells in the control. The control $(0 \mu \mathrm{g} / \mathrm{mL})$ OVCAR-3 cells display a normal round shape and remain firmly attached to the culture plate. Meanwhile, cells treated with VC F7 resulted in morphological alterations and exhibited characteristics such as loss of cellular membrane integrity, cell shrinkage, cell membrane damage, organelle breakdown, and detachment from the culture plate. Acridine orange/propidium iodide is a rapid, sensitive, and successful method to examine cellular morphology, live and dead cells, apoptosis and/or necrosis.
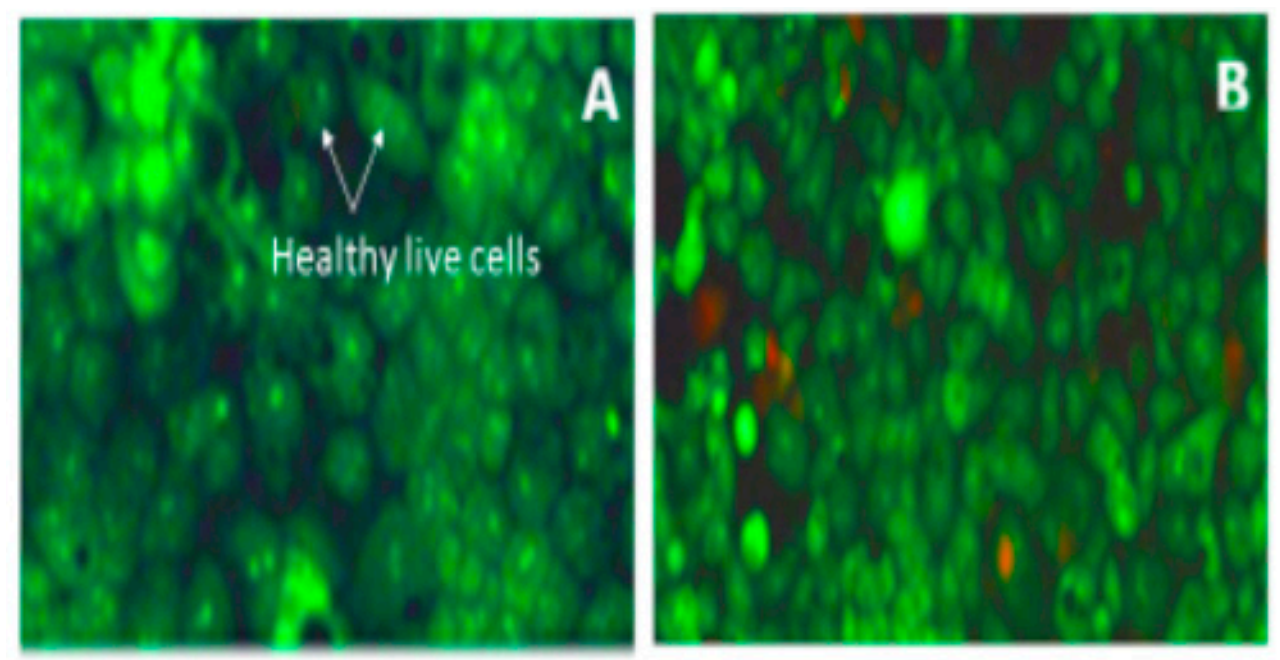

Figure 2. Cont. 

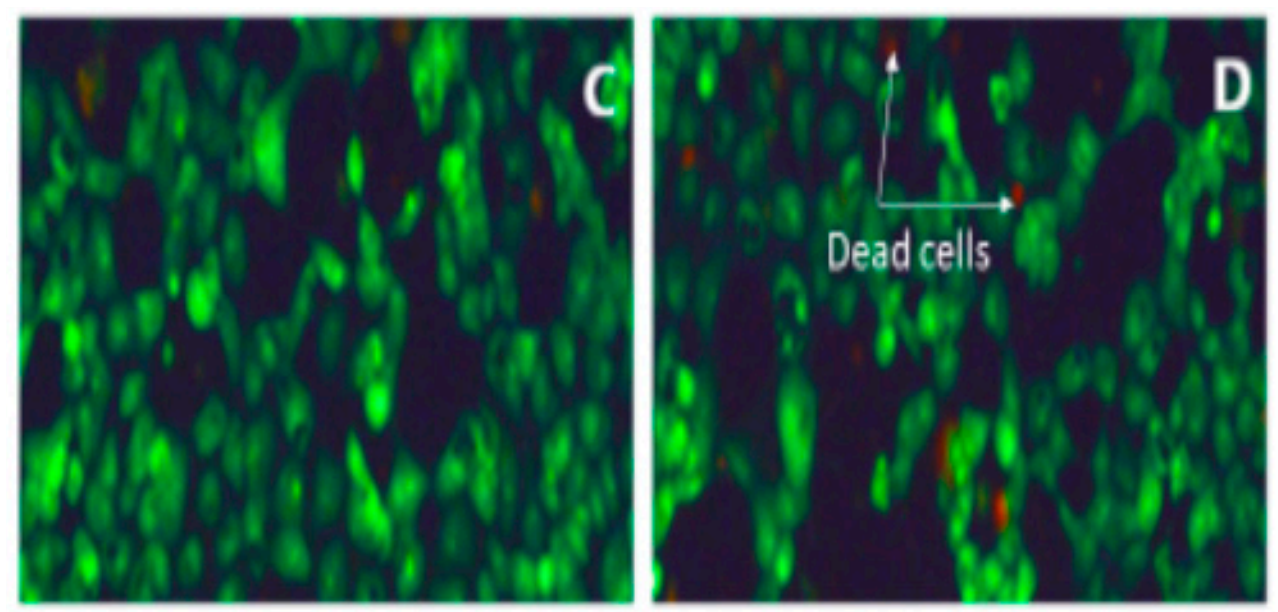

Figure 2. Representative fluorescence images of AO/PI-stained OVCAR-3 cells untreated and treated with VC F7. Live cells are stained in green and dead cells are stained red. (A) - Control, (B) $-8 \mu \mathrm{g} / \mathrm{mL}$, (C) $-16 \mu \mathrm{g} / \mathrm{mL},(\mathbf{D})-32 \mu \mathrm{g} / \mathrm{mL}$. All fluorescence images were captured under 20× optical resolution of the microscope.

\subsection{Induction of Oxidative Stress}

To test whether oxidative stress play a role in VC F7 inducing the antiproliferative effect against ovarian cancer cells, we measured the levels of lipid peroxidation, catalase, and glutathione peroxidase in OVCAR-3 cells. Our result obtained from lipid peroxidation assay showed a significant $(p<0.05)$ increase in the production of malondialdehyde (a by-product of lipid peroxidation and biomarker of oxidative stress) in VC F7-treated cells compared to the control (Figure 3). Upon $48 \mathrm{~h}$ of treatment, the MDA values were $0.044 \pm 0.058,0.140 \pm 0.034,0.209 \pm 0.010$, and $0.324 \pm 0.017 \mathrm{nmol}$ in $0,8,16$, and $32 \mu \mathrm{g} / \mathrm{mL}$ of VC F7, respectively.

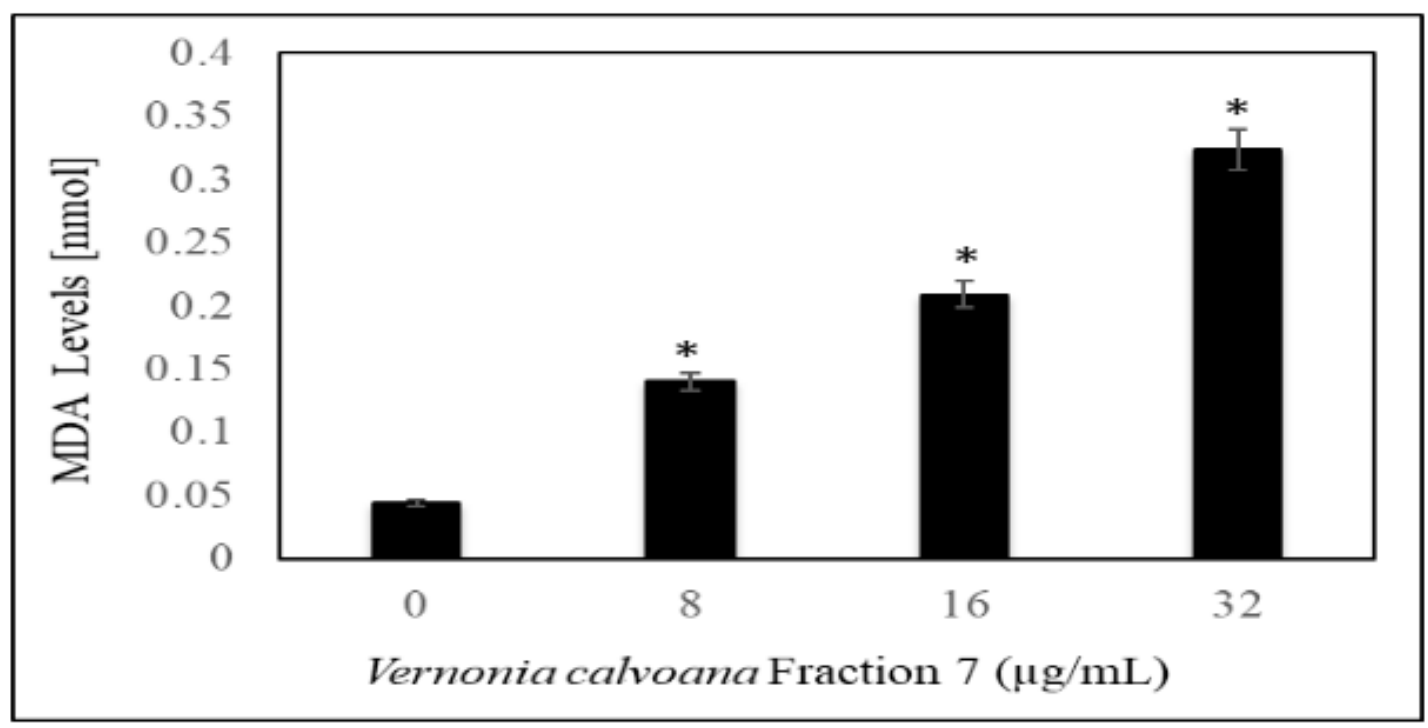

Figure 3. Effect of Vernonia calvoana fraction 7 (VC F7) on MDA production in untreated and treated OVCAR-3 cells for $48 \mathrm{~h}$. The doses that were found to be statistically significantly different $(p<0.05)$ compared to the control are denoted by $\left(^{*}\right)$ according to ANOVA Dunnett.

To further understand the ability of VC F7 to induce oxidative stress in OVCAR-3 cells, we determined the activity of catalase. Data generated from catalase assay demonstrated that VC F7 slightly decreased the activity of catalase at 8 and $16 \mu \mathrm{g} / \mathrm{mL}$ of treatment. When cells were treated with VC F7 at $32 \mu \mathrm{g} / \mathrm{mL}$, catalase activity showed a significant decrease $(p<0.05)$ compared 
to the control. The catalase activities were found to be $0.14 \pm 0.07853,0.13 \pm 0.001,0.13 \pm 0.0001$, and $0.048 \pm 0.000416 \mathrm{n} / \mathrm{mol}$ in $0,8,16$, and $32 \mu \mathrm{g} / \mathrm{mL}$ of VC F7, respectively (Figure 4).

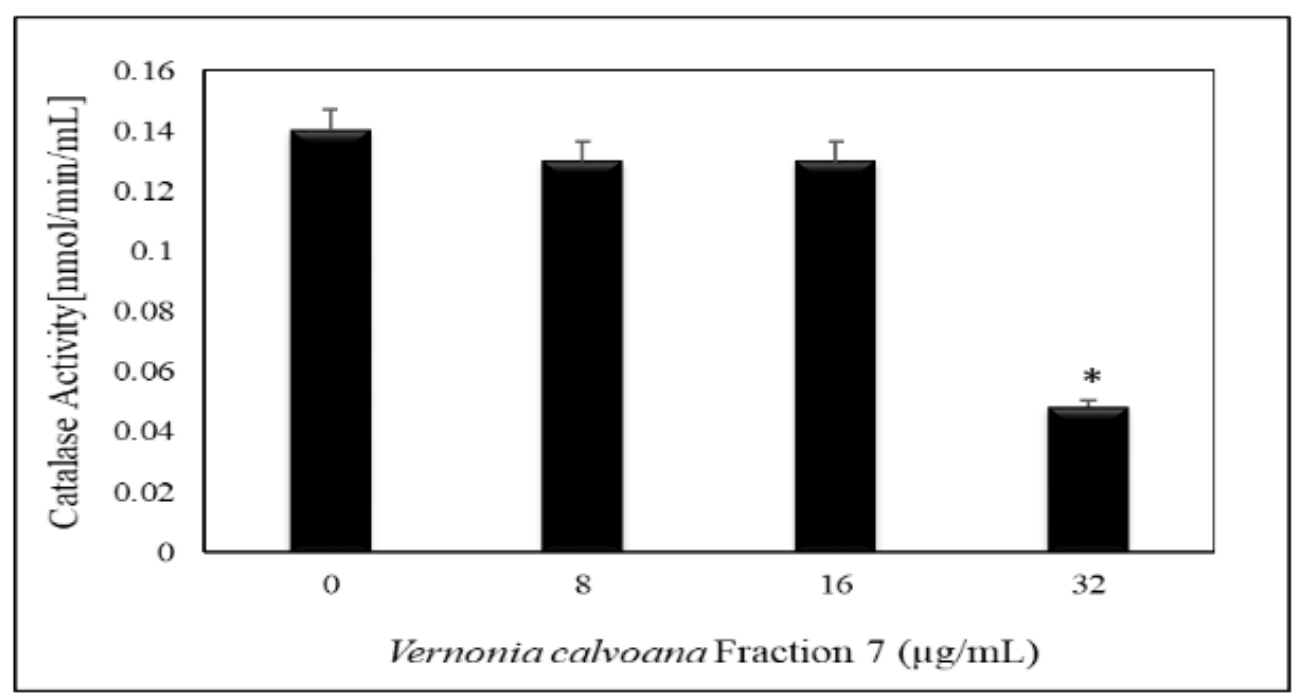

Figure 4. Effect of Vernonia calvoana fraction 7 (VC F7) on catalase activity in untreated and treated OVCAR-3 cells for $48 \mathrm{~h}$. The doses that were found to be statistically significantly different $(p<0.05)$ compared to the control are denoted by $\left(^{*}\right)$ according to ANOVA Dunnett.

To confirm our observations with the catalase activities, we performed a glutathione peroxidase assay. Data generated from the glutathione peroxidase assay showed a gradual decrease in glutathione peroxidase activity in OVCAR-3 cells treated with VC F7 compared to the vehicle control (Figure 5).

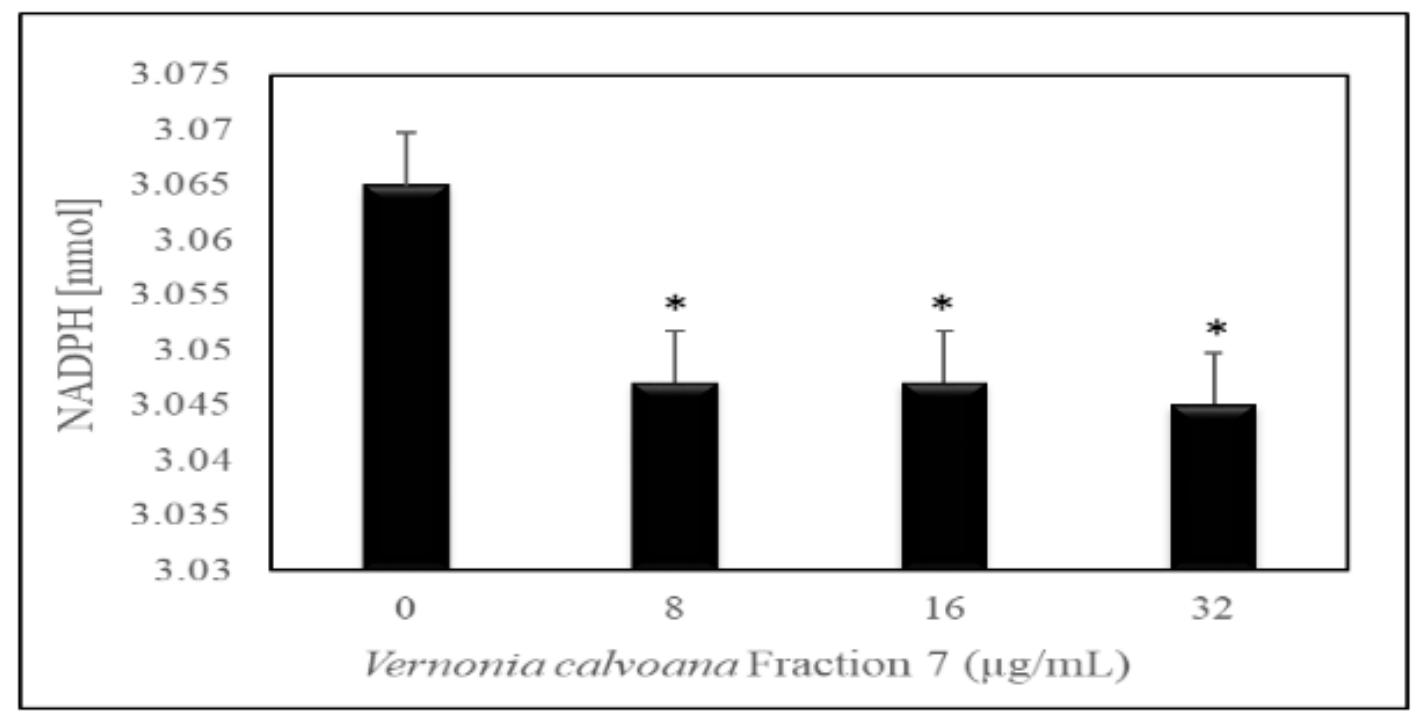

Figure 5. Effect of Vernonia calvoana fraction 7 (VC F7) on glutathione peroxidase activity in untreated and treated OVCAR-3 cells for $48 \mathrm{~h}$. The doses that were found to be statistically significantly different $(p<0.05)$ compared to the control are denoted by $\left({ }^{*}\right)$ according to ANOVA Dunnett.

\subsection{Induction of DNA Damage}

To assess the ability of VC F7 to induce DNA damage in OVCAR-3 cells, we performed a comet assay. Data generated from this assay showed a gradual increase in the mean values of comet tail length, tail moment, and percentages of DNA cleavage of OVCAR-3 cells, with increasing doses of VC F7 (Figure 6). After $48 \mathrm{~h}$ of treatment, the percentages of DNA cleavage were computed to be 
$3.46 \pm 0.043 \%, 21 \pm 0.953 \%, 33.77 \pm 0.529 \%$, and $51.46 \pm 0.353 \%$ in the respective amounts of $0,8,16$, and $32 \mu \mathrm{g} / \mathrm{mL}$ of VC F7 (Figure 7A). In the same order, the mean comet tail lengths computed were $7.47 \pm 0.16,27 \pm 0.23,56.44 \pm 0.53$, and $69 \pm 0.45 \mu \mathrm{M}$ in the respective amounts of $0,8,16$, and $32 \mu \mathrm{g} / \mathrm{mL}$ of VC F7 (Figure 7B).
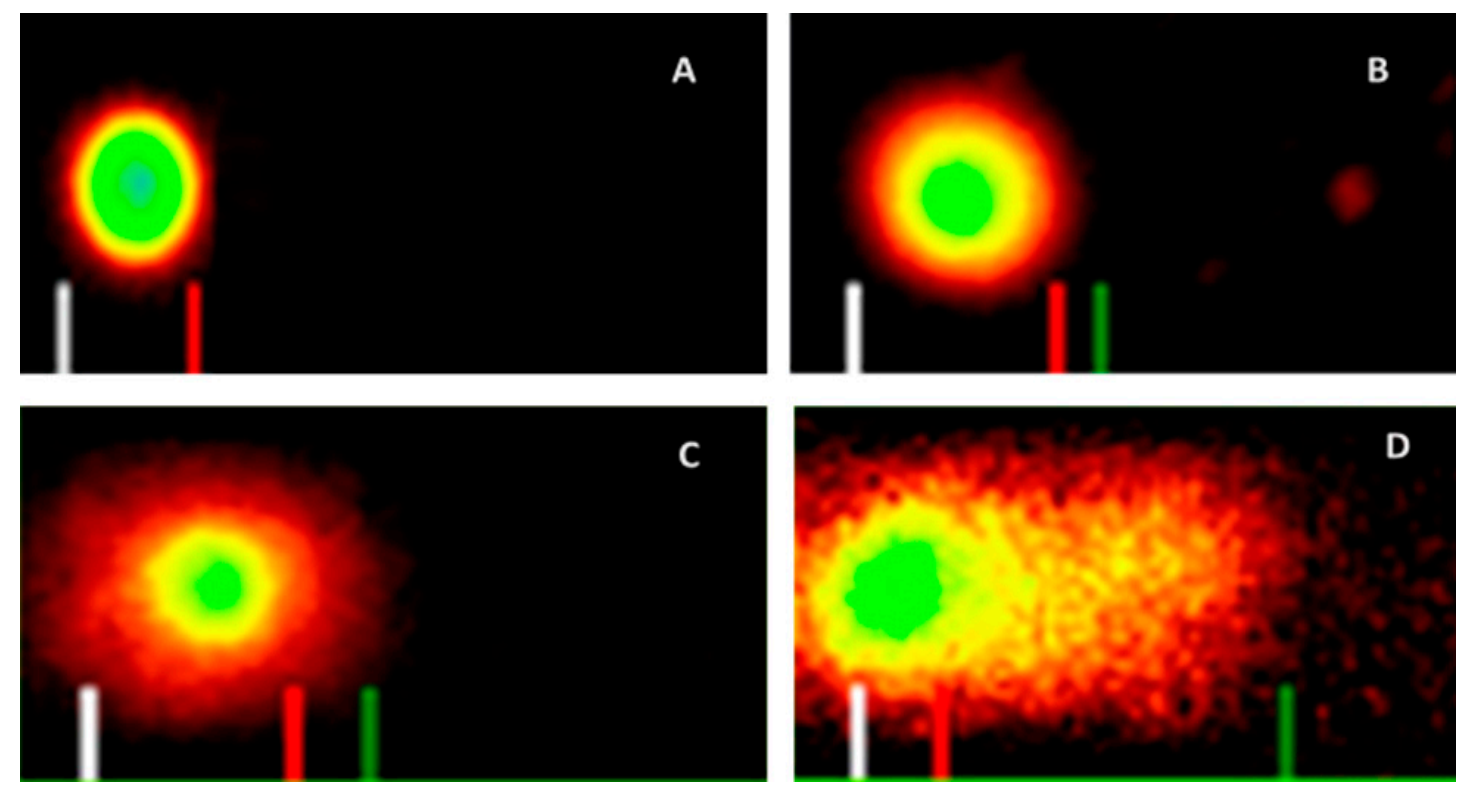

Figure 6. Representative SYBR green comet assay images of untreated (A-control) and Vernonia calvoana fraction 7 (VC F7)-treated cells at $8 \mu \mathrm{g} / \mathrm{mL}$ (B), $16 \mu \mathrm{g} / \mathrm{mL}$ (C), and $32 \mu \mathrm{g} / \mathrm{mL}$ (D) for $48 \mathrm{~h}$.
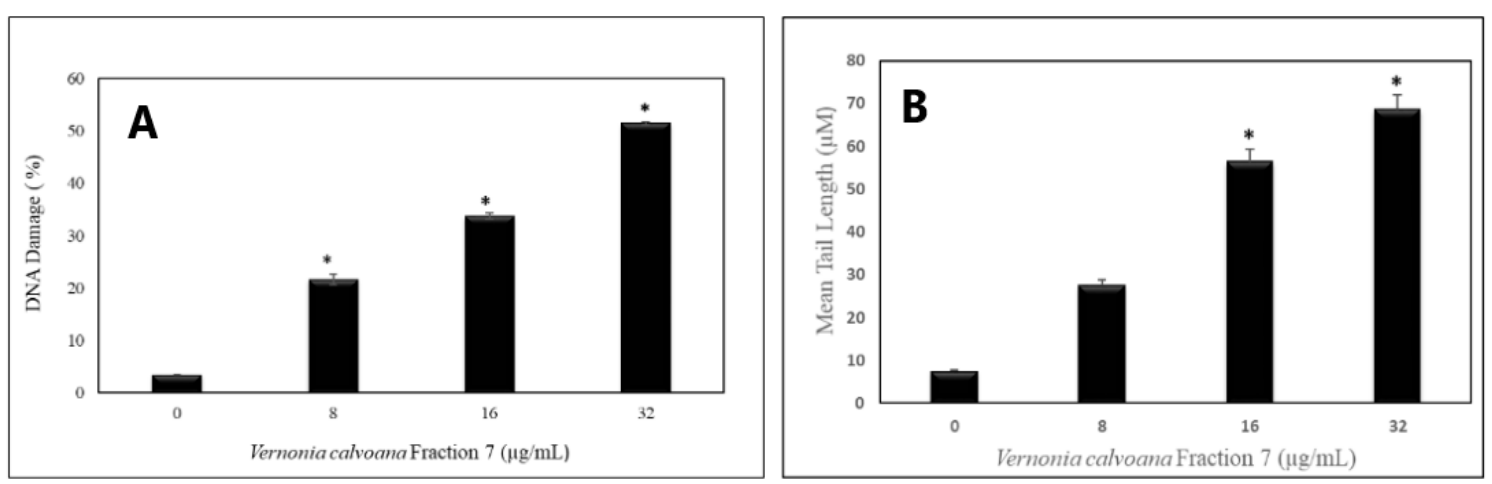

Figure 7. Vernonia calvoana fraction 7-induced DNA damage in OVCAR3 cells was measured by the comet assay. The OVCAR-3 cells were treated with different doses of VC F7 for $48 \mathrm{~h}$. (A) represents the percentage of DNA cleavage and (B) represents the comet tail length. ${ }^{*} p<0.05$ considered significant.

\subsection{Induction of Cell Cycle Arrest}

Here, our aim was to analyze the effects of VC F7 on cell cycle phases and find out at which phase/stage ceases the cycle. Treatment of OVCAR3 cells with VC F7 significantly increases cell population within the S-phase and significantly reduces it in the G2/M-phase (Figures 8 and 9), indicating that VC F7 treatment causes cell cycle arrest at the S-phase checkpoint. The cell cycle arrest at the S-phase implies that the cell is unable to duplicate its DNA. Figure 8 shows the percentage of cells at the G0/G1, S, and G2/M regions. As seen in Figure 8, a cell cycle arrest at the S-phase is associated with a reduction in the G2/M-phase. Figure 9 shows representative dots plots and a histogram of cell cycle distribution of OVCAR-3 cells treated and untreated with VC-F7. 


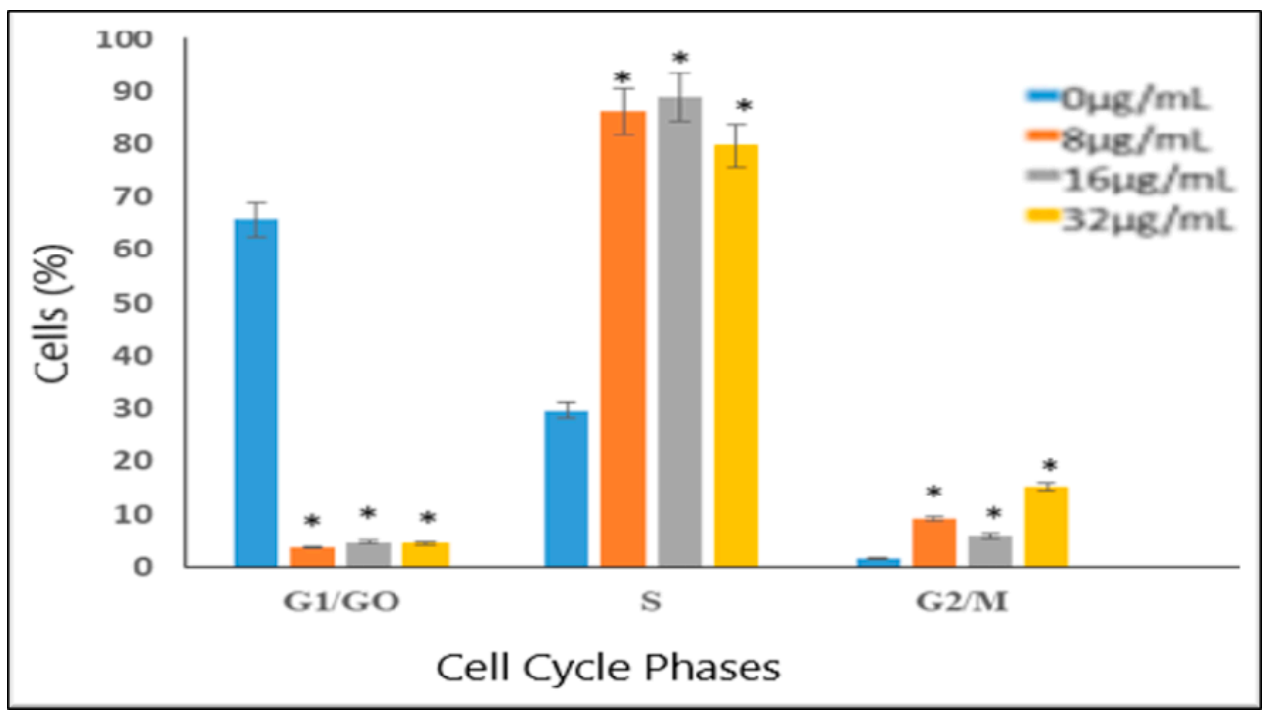

Figure 8. Bar graph showing percentage (\%) of OVCAR-3 cells in different phases of the cell cycle. Each point represents the mean \pm standard deviation of three independent experiments. * denotes statistically significant difference between the control and the treated group according to ANOVA $(p<0.05)$.

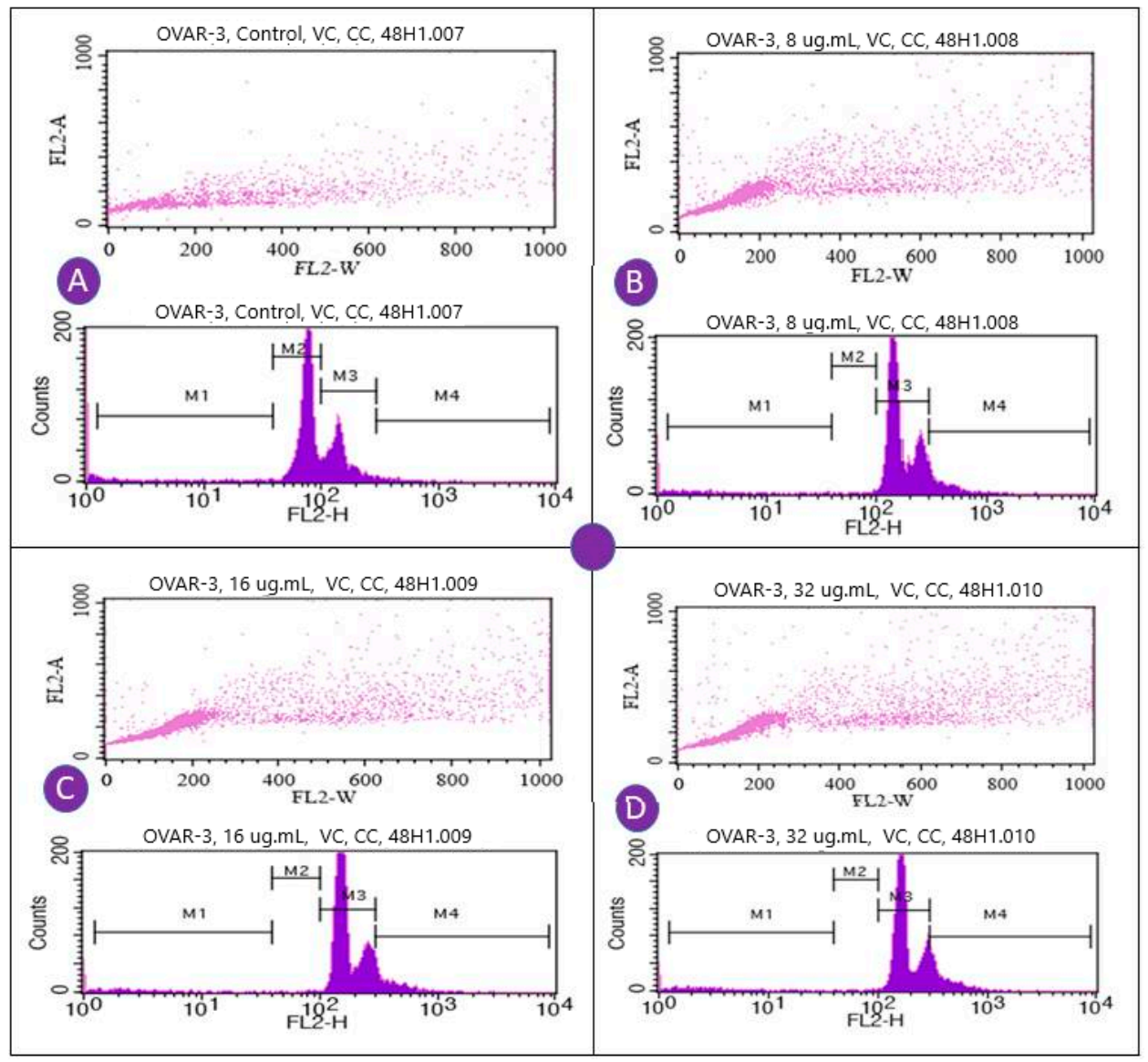

Figure 9. Representative dots plots and histogram showing cell cycle distribution of OVCAR-3 cells treated with VC-F7. The cells were fixed with methanol, stained with PI, and analyzed by flow cytometry (FACS Calibar; Becton-Dickinson) using CellQuest software as described in the Methods section. (A) $0 \mu \mathrm{g} / \mathrm{mL}$, (B) $8 \mu \mathrm{g} / \mathrm{mL}$, (C) $16 \mu \mathrm{g} / \mathrm{mL}$, (D) $32 \mu \mathrm{g} / \mathrm{mL}$. Three experiments were performed, and one (1) representative experiment is shown. 


\section{Discussion}

\subsection{Antiproliferative Effect}

In the present study, we first evaluated the antiproliferative effect of VC F7 on OVCAR-3 cells by the means of MTS assay. Our results demonstrated that VC F7 significantly $(p<0.05)$ reduces the percentage of live cells in a dose-dependent manner, suggesting its antiproliferative effect against ovarian cancer (Figure 1). We further evaluated the antiproliferative effect of VC F7 and morphological changes of OVCAR-3 cells by the means of AO/PI assay. We observed that VC F7 gradually inhibits the proliferation of OVCAR-3 cells and causes morphological changes of these cells (Figure 2). As seen in Figure 2, the untreated OVCAR-3 cells display a normal round shape, have about $90 \%$ confluency, and remain firmly attached to the culture plate. However, cells treated with VC F7 resulted in morphological alterations and exhibited characteristics such as loss of cellular membrane integrity, cell shrinkage, cell membrane damage, organelle breakdown, apoptotic bodies, and detachment from the culture plate [25]. We previously observed similar results while testing the antitumor activity of Vernonia amygdalina, a species of the same family as Vernonia calvoana [26]. In Cameroon, the leaves of Vernonia amygdalina, Vernonia calvoana, and Vernonia amygdalina Delile plants are used extensively as leaf vegetables and form a major constituent of a stew called ndole. The medicinal properties of these plants are well-documented and are commonly recommended by herbalists to patients in African countries for the treatment of headaches, stomach-aches [27], gastrointestinal tract problems [28], loss of appetite, breast milk enhancement in nursing mothers [29], bacterial infections, liver diseases, kidney problems [30], hypertension and diabetes [20,31], and cancer [24,32]. Animals use these medicinal plants to cure themselves and there is scientific evidence in which chimpanzees inhabiting the Mahale Mountains National Park in Tanzania have been observed chewing the pith of the leaves of Vernonia Amygdalina. Possible benefits include Vernonia's ability to ward off parasites and to treat gastrointestinal tract infections [33]. Interestingly, the chimpanzees' health condition gradually improved within a day and they resumed their normal activity. According to statistics, herbal and plant-derived medicines are the most frequently used therapies worldwide. A large number of people in developing countries depend on these natural remedies to maintain healthcare and a $38 \%$ increase in usage in the United States within the last decade of the 20th century alone has been reported [34,35]. It has been shown that natural medicinal plants work with the body to boost the immune system by killing unhealthy cells [36,37]. A previous scientific report indicated that VC possesses a hepatoprotective effect and hypolipidemic and antidiabetic activities [20].

\subsection{Induction of Oxidative Stress}

Given the effectiveness of VC F7 to inhibit the growth of OVCAR-3 cells, we hypothesized that the antiproferative effect of VC F7 may be mediated through oxidative stress. To test our hypothesis, we measured the levels of lipid peroxidation, catalase, and glutathione peroxidase in OVCAR-3 cells treated with VC F7. Oxidative stress plays an important role in cancer initiation and progression [38]. Our result obtained from lipid peroxidation assay showed a significant $(p<0.05)$ increase in the production of malondialdehyde (MDA - a by-product of lipid peroxidation and biomarker of oxidative stress) in VC F7-treated cells compared to the control. This finding is consistent with previous studies in our lab showing that Vernonia amygdalina Delile crude extract acts as a pro-oxidant in prostate cancer (PC-3) cells at a high concentration [39]. We also previously demonstrated that garlic extract significantly induced MDA production in the HL-60 human leukemia cell in a dose-dependent manner [39].

Our hypothesis that the antiproferative effect of VC F7 may be mediated through oxidative stress was also tested by catalase assay. Catalase is an enzyme that neutralizes the burden of $\mathrm{H}_{2} \mathrm{O}_{2}$ in cells by decomposing this molecule into water and oxygen. Catalase activity intercepts the oxidative damage that is triggered by high levels of $\mathrm{H}_{2} \mathrm{O}_{2}$. Studies have shown that the presence of high levels of $\mathrm{H}_{2} \mathrm{O}_{2}$ 
increases the speed of DNA mutation $[40,41]$. Our result revealed a gradual decrease in catalase activity in VC F7-treated cells when compared to the control.

To further understand the ability of VC F7 to induce oxidative stress in OVCAR-3 cells, we examined the activity of glutathione peroxidase. Glutathione peroxidase is localized in the cytosol and mitochondria, and research suggests that it may degrade low levels of hydrogen peroxide-one of the main ROS involved in arsenic-induced DNA damage [42,43]. Data demonstrated that VC F7 significantly $(p<0.05)$ decreases the levels of glutathione content. Depletion of glutathione level is associated with the early stage of the initiation of cell death $[44,45]$.

Taken together, our results of oxidative stress are in agreement with a previous study showing that extracts of Alhagi maurorum increased the production of MDA levels, decreased the content of GSH, and decreased the activities of antioxidant enzymes including SOD, GPx, and GST in livers of STZ-induced diabetic rats [46].

\subsection{Induction of DNA Damage}

The ability of VC F7 to induce DNA damage in OVCAR-3 cells was determined by the means of comet assay. Our results showed that VC F7 induces DNA damage in OVCAR-3 cells in a dose-dependent manner. Untreated cells show low or no DNA migration, indicating that the DNA is intact and undamaged. However, cells treated with VC F7 revealed a gradual increase in DNA cleavage as well as an increase in comet tail length when compared to that of the untreated cells (control). To the best of our knowledge, no data are found in the literature regarding the genotoxic effect of VC in vitro or in vivo. We revealed for the first time that VC F7 induces DNA damage in OVCAR-3 cells, supporting its ability as a potential DNA-damaging anticancer agent effective against ovarian cancer. Working with other Vernonia species, previous reports from our laboratory demonstrated that in vitro Vernonia amygdalina treatment reduces cellular viability, that is, it induces DNA damage leading to apoptosis accompanied by secondary necrotic cells in human breast cancer (MCF-7) cells [21,22]. In another study, we showed that Vernonia amygdalina Delile induced DNA damage in human leukemia (HL-60) cells and human prostate cancer (PC-3) cells [24].

\subsection{Induction of Cell Cycle Arrest}

To assess the effects of VC F7 on cell cycle and population distribution, OVCAR-3 cells were stained with propidium iodide and analyzed by flow cytometry. We found that 48 -h VC F7 treatment induced significant cell cycle arrest in the S-phase $(p<0.05)$ in comparison to untreated cells. The cell cycle arrest in the S-phase is a direct result of VC F7 inhibition of cell growth and induction of DNA damage in OVCAR-3 cells via oxidative stress (Figure 10). Consistent with our data, many natural products exhibit inhibitory effects on cancer cells via disruption of cell cycle progression. For example, studies showed that Ganoderma extract caused cell cycle arrest in cancer cells [47]. The growth inhibitory effect of celery seed extracts on human gastric cancer BGC-823 cells caused cell cycle arrest at the S-phase and decreased levels of cyclin A and CDK-2 [48,49]. The crude water extract of Centella asiatica showed $\mathrm{S}$ and G2/M arrest in human colon adenocarcinoma-derived Caco-2 cells, accompanied with the accumulation of cyclin B1 protein [50,51]. In addition, our results are in agreement with those of curcumin (diarylheptanoid derivative of turmeric), indicating that it inhibits cell proliferation by altering the cell cycle in different cancer cells $[52,53]$. 


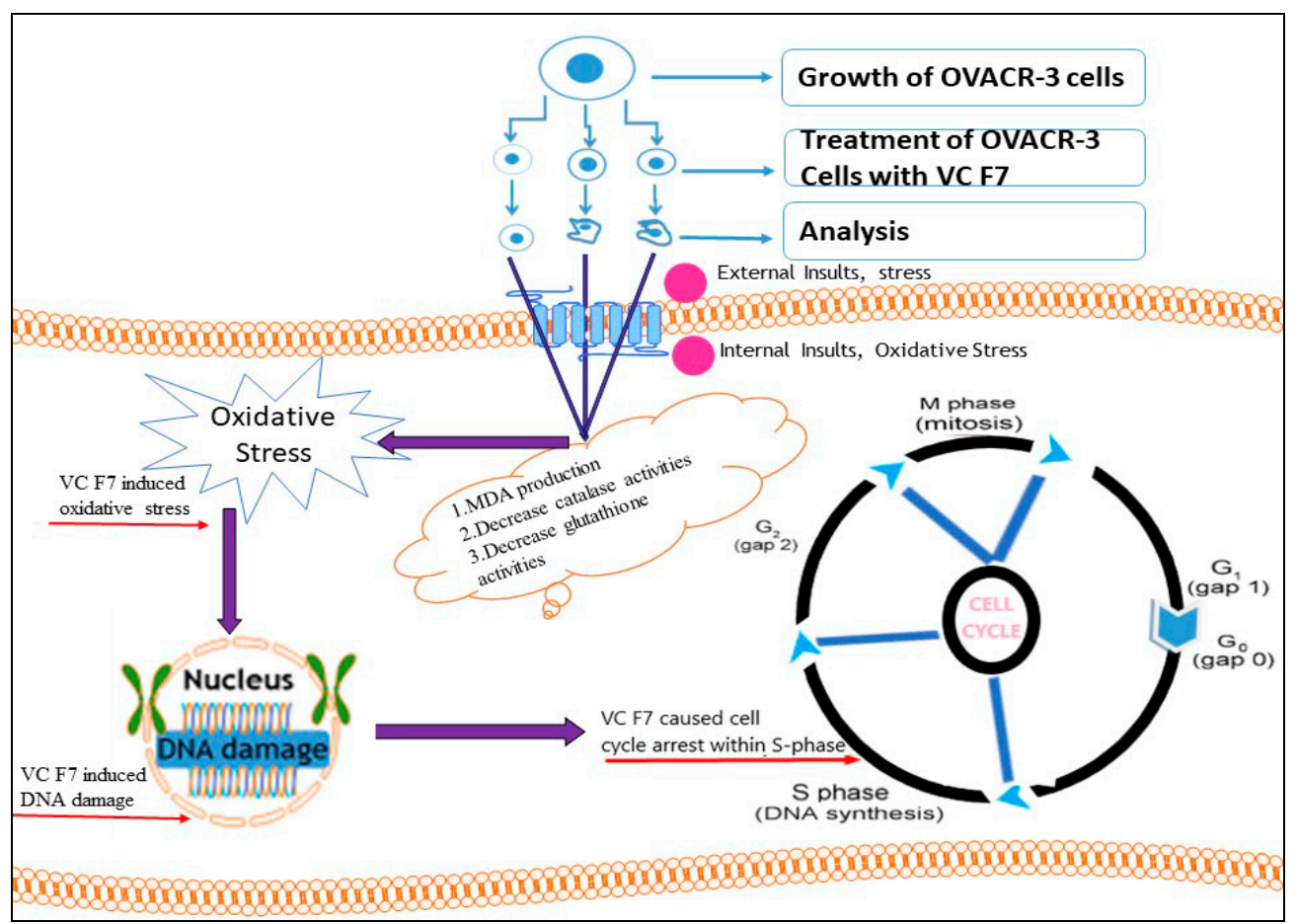

Figure 10. Underlying mechanisms by which Vernonia calvoana fraction 7 (VC F7) exerts its antitumor activity in human ovarian cancer (OVAR-3) cells.

\section{Materials and Methods}

\subsection{Chemicals and Media}

The growth medium RPMI 1640 containing $1 \mathrm{mmol} / \mathrm{L}$ L-glutamine, fetal bovine serum (FBS), phosphate buffered saline (PBS), and penicillin streptomycin were purchased from the American Type Culture Collection (ATCC) in Manassas, VA. The MTS assay kit was purchased from Promega Life Sciences (Madison, WI, USA). The lipid peroxidation, glutathione peroxidase, and catalase assay kits were purchased from Abcam (Cambridge, MA, USA). The comet assay kit was obtained from Trevigen (Gaithersburg, MD, USA). The propidium iodide was purchased from Calbiochem (La Jolla, CA, USA).

\subsection{Vernonia calvoana Preparation and Fractionation}

Leaves of Vernonia calvoana were harvested in Bangou, Cameroon. The leaves were rinsed and air-dried under the sun for a day. This was followed by shade-drying for 5 days. Five hundred grams of dried leaves were mixed with $600 \mathrm{~mL}$ of methanol and heated at $50{ }^{\circ} \mathrm{C}$. The mixture was filtered with Whatman No 1 filter paper and evaporate to dryness using a rotary evaporator. Vernonia calvoana extracts were kept refrigerated at $4{ }^{\circ} \mathrm{C}$ until use. Fractionation of plant extract was performed according to Ogungbe et al. (2014) [54] and Abugri et al. (2016) [55]. The fractions were collected and stored in a freezer at $-4{ }^{\circ} \mathrm{C}$.

\subsection{Cell Culture}

Human ovarian adenocarcinoma (OVCAR-3) cells were purchased from the American Type Culture Collection. They were then sub-cultured in RPMI-1640 medium, supplemented with $10 \%$ fetal bovine serum and $1 \%$ penicillin/streptomycin (Thermo Scientific, Waltham, MA, USA), and grown in an incubator at $37^{\circ} \mathrm{C}$ in $5 \% \mathrm{CO}_{2}$. Fresh medium was supplemented every $48 \mathrm{~h}$. 


\subsection{Cell Treatment and Determination of Cell Viability}

The antiproliferative effects of VC F7 on the viability of OVCAR-3 cells was determined by the MTS colorimetric assay. We used fraction 7 because it showed the highest antitumor activity towards ovarian cancer cells compared to other fractions present in the crude extract. Cells were seated in 96-well plates at a density of $5 \times 10^{3}$ cells per well were treated with different doses $(0,8,16$, and $32 \mu \mathrm{g} / \mathrm{mL})$ of VC F7 for $48 \mathrm{~h}$. After cells treatment, the medium was carefully aspirated from the treated plate and replace with an aliquot $(100 \mu \mathrm{L})$ of fresh medium. Then, $20 \mu \mathrm{L}$ of the MTS solution was added to each well and incubated for $3 \mathrm{~h}$. The absorbance was read at $490 \mathrm{~nm}$ using a Biotex Model micro plate reader.

\subsection{Morphological Changes}

In this assay, we explore the morphological changes of OVCAR-3 cells treated and untreated with VC F7. Briefly, cells seated in each polystyrene 6 well-plate were treated with VC F7 for $48 \mathrm{~h}$. After treatment, cells were washed twice with PBS and stained with a double dye (acridine orange (AO) and propidium iodide (PI). After staining, cells were examined and photographed under an Olympus fluorescent microscope.

\subsection{Measurement of Lipid Peroxidation/Malondiadehyde}

For this experiment, cells seeded in a 6-well plate at a density of $5 \times 10^{6}$ cells/well were treated with different doses $(0,8,16$, and $32 \mu \mathrm{g} / \mathrm{mL})$ of VC F7 for $48 \mathrm{~h}$. Cells were harvested, centrifuged, and collected in a $15 \mathrm{~mL}$ test tube. The cell pellets were lysed in $200 \mu \mathrm{L}$ malondialdehyde (MDA) lysis buffer plus $2 \mu \mathrm{L}$ BHT (100x) The freeze-thaw method was then carried out, and then $200 \mathrm{uL}$ aliquots of the culture medium was assayed for MDA according to the lipid peroxidation assay protocol as previously described [56,57]. The absorbance was measured at $586 \mathrm{~nm}$ and the concentration of MDA was estimated from the standard curve. Experiments were performed in triplicates.

\subsection{Measurement of Catalase Activity}

Catalase activity was estimated by the means of catalase assay activity kit from Abcam company. Cells treated with different doses $(0,8,16$, and $32 \mu \mathrm{g} / \mathrm{mL})$ of VC F7 for $48 \mathrm{~h}$. Treated and untreated cells were harvested, centrifuged, and collected in a $15-\mathrm{mL}$ test tube. Cells were digested and catalase activity was determined according to the protocol as previously described with a few modifications [58]. Experiments were performed in triplicates.

\subsection{Measurement of Glutathione Peroxidase Activity}

To estimate the glutathione activity in this study, OVCAR-3 cells were seeded in a 6-well plate and treated with different doses of VC F7 for $48 \mathrm{~h}$. Cells were digested and intracellular glutathione levels were determined using the assay kits purchased from Abcam (Cambridge, MA) according to the protocol previously described with some modifications [59]. Experiments were performed in triplicates.

\subsection{Assessment of DNA Damage}

For this experiment, OVCAR-3 cells were treated with VC F7 at doses of 8,16 , and $32 \mu \mathrm{g} / \mathrm{mL}$ for $48 \mathrm{~h}$. Briefly, an aliquot $50 \mu \mathrm{L}$ cell suspension was mixed with $200 \mu \mathrm{L}$ of agarose. Then, $75 \mu \mathrm{L}$ of the mixture was spread on the comet slides and place in the refrigerator for $15 \mathrm{~min}$. The slides were immersed in lysis solution for $60 \mathrm{~min}$ at $4{ }^{\circ} \mathrm{C}$. They were further immersed in a prepared alkaline solution and kept in the dark for $60 \mathrm{~min}$. Sample slides were electrophoresed at $21 \mathrm{~V}$ for $30 \mathrm{~min}$, dehydrated in 70\% ethanol for $5 \mathrm{~min}$, and stained with DNA- bound SYBR green I fluorescence stain overnight. The samples were visualized for DNA damage under a fluorescent microscope at 494/521 nm wavelength where several images were taken. The images were analyzed using the Trevigen Comet Assay software. 


\subsection{Assessment of Cell Cycle Distribution}

All steps for this experiment were performed at $0^{\circ} \mathrm{C}$. Briefly, cells were seeded into a 6-well plates at the density of $6 \times 10^{6}$ cells/well and treated with different doses $(0,8,16$, and $32 \mu \mathrm{g} / \mathrm{mL})$ of VC F7 for $48 \mathrm{~h}$. After treatment, cells were harvested, washed twice with PBS, and fixed in ice-cold methanol for $30 \mathrm{~min}$ at $4{ }^{\circ} \mathrm{C}$. Cells were stained with propidium iodide in the presence of RNase $\mathrm{A}$ and incubated for $30 \mathrm{~min}$ at room temperature. After staining, cells were analyzed by flow cytometry (BD Biosciences, San Jose, CA, USA).

\section{Conclusions}

New therapeutic approaches for the screening of bioactive compounds present in medicinal plants have received increasing attention due to their chemopreventive properties such as anti-oxidative, anti-cancer, and anti-inflammatory activities [60-62]. Studies indicated that Vernonia calvoana contained high concentrations of flavonoids rich in antioxidants which are natural substances that prevent cellular damage in living organisms. In the present study, we demonstrated that VC F7 is able to inhibit cell proliferation, induce DNA damage and cell cycle arrest at the S-phase checkpoint of the cell cycle in human ovarian cancer (OVAR-3) cells through oxidative stress, as demonstrated by an increase in MDA production and a decrease in catalase and glutathione activities in treated cells compared to the control. All these unique properties of VC F7 against OVAR-3 cells strongly suggest that VC F7 may be a novel and potential targeting molecule that can be used as a therapeutic agent for ovarian cancer. It is noteworthy that VC F7 exerts its anticancer activity by inhibiting cell proliferation, inducing DNA damage, and causing cell cycle arrest through oxidative stress in OVAR-3 cells. However, future preclinical and clinical trial studies are needed to test the medicinal properties of VC F7 as an alternative therapeutic agent for the prevention and/or treatment of ovarian cancer. Future research in our lab will focus on the identification and characterization of the active constituents present in CV F7 and testing antitumor activity in an animal model.

Author Contributions: A.T.M. and C.G.Y. conceived, and designed the study. A.T.M. and J.N.S. performed the experiments and drafted the manuscript. C.G.Y., P.B.T. supervised the experiments and assisted in performing data interpretation. F.K.N. and C.R.G. provided a critical review and manuscript editing. A.T.M., C.G.Y., and P.B.T. participated in the implementation of the study and reviewed the manuscript for submission. All authors have read and agreed to the published version of the manuscript.

Funding: This work was financially supported by a grant from the National Institutes of Health (NIH) under grant \# G12MD007581 through the RCMI Center for Environmental Health, and partly by NIH under grant \# 1R03CA223099-01A1 at Jackson State University. The content is solely the responsibility of the authors and does not necessarily represent the official view of NIH.

Acknowledgments: This research was made possible with the support from the Ph.D. Environmental Science Program at Jackson State University.

Conflicts of Interest: The authors declare no conflict of interest.

\section{References}

1. Siegel, R.L.; Miller, K.D.; Jemal, A. Cancer statistics, 2019. CA. Cancer J. Clin. 2019, 69, 7-34. [CrossRef] [PubMed]

2. American Cancer Society. Breast Cancer Facts \& Figures 2017-2018; American Cancer Society, Inc.: Atlanta, GA, USA, 2017.

3. Jones, M.R.; Kamara, D.; Karlan, B.Y.; Pharoah, P.D.P.; Gayther, S.A. Genetic epidemiology of ovarian cancer and prospects for polygenic risk prediction. Gynecol. Oncol. 2017, 147, 705-713. [CrossRef] [PubMed]

4. Committee on Practice Bulletins-Gynecology, Committee on Genetics, Society of Gynecologic Oncology. Practice Bulletin No 182: Hereditary Breast and Ovarian Cancer Syndrome. Obstet. Gynecol. 2017, 130, e110-e126. [CrossRef] [PubMed]

5. Friebel, T.M.; Domchek, S.M.; Rebbeck, T.R. Modifiers of cancer risk in $\mathrm{BRCA}_{1}$ and $\mathrm{BRCA}_{2}$ mutation carriers: Systematic review and meta-analysis. J. Natl. Cancer Inst. 2014, 106, 235. [CrossRef] 
6. Moorman, P.G.; Havrilesky, L.J.; Gierisch, J.; Coeytaux, R.R.; Lowery, W.J.; Urrutia, R.P.; Dinan, M.; McBroom, A.J.; Hasselblad, V.; Sanders, G.D.; et al. Oral contraceptives and risk of ovarian cancer and breast cancer among high-risk women: A systematic review and meta-analysis. J. Clin. Oncol. 2013, 31, 4188-4198. [CrossRef]

7. Cibula, D.; Zikan, M.; Dusek, L.; Majek, O. Oral contraceptives and risk of ovarian and breast cancers in BRCA mutation carriers: A meta-analysis. Expert Rev. Anticancer Ther. 2011, 11, 1197-1207. [CrossRef]

8. Miller, K.D.; Havrilesky, L.J.; Gierisch, J.M.; Coeytaux, R.R.; Lowery, W.J.; Dinan, R.P.U.M.; McBroom, A.J.; Hasselblad, V.; Sanders, G.D.; Myers, E.R. Cancer treatment and survivorship statistics, 2016. CA Cancer J. Clin. 2016, 66, 271-289. [CrossRef]

9. Jasen, P. From the 'silent killer' to the 'whispering disease': Ovarian cancer and the uses of metaphor. Med. Hist. 2009, 53, 489-512. [CrossRef]

10. Torre, L.A.; Trabert, B.; DeSantis, C.E.; Miller, K.D.; Samimi, G.; Runowicz, C.D.; Gaudet, M.M.; Jemal, A.; Siegel, R.L. Ovarian cancer statistics, 2018. CA Cancer J. Clin. 2018, 68, 284-296. [CrossRef]

11. Howlader, N.; Noone, A.M.; Krapcho, M.; Miller, D.; Bishop, K.; Kosary, C.L.; Yu, M.; Ruhl, J.; Tatalovich, Z.; Mariotto, A.; et al. (Eds.) SEER Cancer Statistics Review, 1975-2014; National Cancer Institute: Bethesda, MD, USA, 2017. Available online: http://Seer.Cancer.Gov./Csr/1975_2014/ (accessed on 1 April 2017).

12. Matsuo, K.; Lin, Y.G.; Roman, L.D.; Sood, A.K. Overcoming platinum resistance in ovarian carcinoma. Expert Opin. Investig. Drugs 2010, 19, 1339-1354. [CrossRef]

13. Kim, M.; Suh, D.H.; Lee, K.-H.; Eom, K.-Y.; Toftdahl, N.G.; Mirza, M.R.; Kim, J.-W. Major clinical research advances in gynecologic cancer in 2018. J. Gynecol. Oncol. 2019, 30, e18. [CrossRef]

14. Wright, A.A.; Bohlke, K.; Armstrong, D.K.; Bookman, M.A.; Cliby, W.A.; Coleman, R.L.; Dizon, D.S.; Kash, J.J.; Meyer, L.A.; Moore, K.N.; et al. Neoadjuvant chemotherapy for newly diagnosed, advanced ovarian cancer: Society of Gynecologic Oncology and American Society of Clinical Oncology Clinical Practice Guideline. Gynecol. Oncol. 2016, 143, 3-15. [CrossRef] [PubMed]

15. Ejoh, R.A.; Nkonga, D.V.; Inocent, G.; Moses, M.C. Nutritional components of some non-conventional leafy vegetables consumed in Cameroon. Pak. J. Nutr. 2007, 6, 712-717. [CrossRef]

16. Igile, G.O.; Iwara, I.A.; Mgbeje, B.I.A.; Uboh, F.E.; Ebong, P.E. Phytochemical, proximate and nutrient composition of Vernonia calvaona Hook (Asterecea): A green-leafy vegetable in Nigeria. J. Food Res. 2013, 2, 6. [CrossRef]

17. Ekor, M. The growing use of herbal medicines: Issues relating to adverse reactions and challenges in monitoring safety. Front. Neurol. 2014, 4, 177. [CrossRef]

18. Toyang, N.J.; Verpoorte, R. A review of the medicinal potentials of plants of the genus Vernonia (Asteraceae). J. Ethnopharmacol. 2013, 146, 681-723. [CrossRef]

19. Egbung, G.E.; Atangwho, I.J.; Kiasira, Z.B.; Iwara, I.A.; Igile, G.O. Antioxidant activity of the inflorescents of Vernonia calvoana growing in Yakurr Local Government Area of Cross River State, Nigeria. Glob. J. Pure Appl. Sci. 2016, 22, 2. [CrossRef]

20. Iwara, I.; Igile, G.; Uboh, F.; Eyong, E.; Ebong, P. Hypoglycemic and Hypolipidemic Potentials of Extract of Vernonia calvoana on Alloxan-Induced Diabetic Albino Wistar Rats. Eur. J. Med. Plants 2015, 8, 78-86. [CrossRef]

21. Yedjou, C.; Izevbigie, E.; Tchounwou, P. Preclinical assessment of Vernonia amygdalina leaf extracts as DNA damaging anti-cancer agent in the management of breast cancer. Int. J. Environ. Res. Public Health 2008, 5, 337-341. [CrossRef]

22. Yedjou, C.G.; Izevbigie, E.B.; Tchounwou, P.B. Induced Growth Arrest and Apoptosis of Breast Cancer (MCF-7) Cells. Pharmacol. Pharm. 2013, 4, 93-99. [CrossRef]

23. Lowe, H.; Daley-Beckford, D.; Toyang, N.; Watson, C.; Hartley, S.; Bryant, J. The anti-cancer activity of Vernonia divaricata Sw against leukaemia, breast and prostate cancers in vitro. West. Indian Med. J. 2014, 63, 285-288. [CrossRef] [PubMed]

24. Johnson, W.; Tchounwou, P.B.; Yedjou, C.G. Therapeutic mechanisms of vernonia amygdalina delile in the treatment of prostate cancer. Molecules 2017, 22, 1594. [CrossRef] [PubMed]

25. Yedjou, C.G.; Tchounwou, S.S.; Williams, K.; Tchounwou, P.B. Novel Cellular Staining Protocol and Antiproliferative effect of vernonia amygdalina delile on lung and prostate cancer cells. Int. J. Eng. Sci Res. Technol. 2018, 7, 552-556. [CrossRef] [PubMed] 
26. Yedjou, C.G.; Tchounwou, P.B.; Miele, L.; Ogungbe, I.V.; Brown, R.J.; Payton, M. Abstract 5313: The anticancer effect of Vernonia amygdalina in the MMTV-PyVT transgenic mouse model. Exp. Mol. Ther. 2015, 75, 5313. [CrossRef]

27. Tugume, P.; Kakudidi, E.K.; Buyinza, M.; Namaalwa, J.; Kamatenesi, M.; Mucunguzi, P.; Kalema, J. Ethnobotanical survey of medicinal plant species used by communities around Mabira Central Forest Reserve, Uganda. J. Ethnobiol. Ethnomed. 2016, 12, 5. [CrossRef]

28. Adedapo, A.A.; Adeoye, B.O.; Sofidiya, M.O.; Oyagbemi, A.A. Antioxidant, antinociceptive and anti-inflammatory properties of the aqueous and ethanolic leaf extracts of Andrographis paniculata in some laboratory animals. J. Basic Clin. Physiol. Pharmacol. 2015, 26, 327-334. [CrossRef]

29. Kankara, S.S.; Ibrahim, M.H.; Mustafa, M.; Go, R. Ethnobotanical survey of medicinal plants used for traditional maternal healthcare in Katsina state, Nigeria. South Afr. J. Bot. 2015, 97, 165-175. [CrossRef]

30. Egbung, G.E.; Odey, O.D.; Atangwho, I.J. Effect of Vernonia calvoana Extract on Selected Serum Kidney Function Biomarkers of Acetaminophen Treated Wistar Rats. Asian J. Biochem. 2017, 12, 99-104. [CrossRef]

31. Asante, D.-B.; Effah-Yeboah, E.; Barnes, P.; Abban, H.A.; Ameyaw, E.O.; Boampong, J.; Ofori, E.G.; Dadzie, J.B. Corrigendum to 'Antidiabetic Effect of Young and Old Ethanolic Leaf Extracts of Vernonia amygdalina: A Comparative Study'. J. Diabetes Res. 2017, 2017, 5618548. [CrossRef]

32. Pandey, A.; Pradheep, K.; Sharma, N. Potential introduced medicinal plant african bitter leaf (Vernonia amygdalina delile) in India: Botany, propagation and uses. Med. Plants 2014, 6, 272. [CrossRef]

33. Bodeker, G. WHO global atlas on traditional, complementary and alternative medicine (TCAM). Iran. J. Pharm. Res. 2010, 3, 25.

34. Barnes, P.M.; Bloom, B.; Nahin, R.L. Complementary and Alternative Medicine use among Adults and Children: United States, 2007. Natl. Health Stat. Rep. 2010, 10, 1-23. [CrossRef]

35. Medicine, A. The Use of Complementary and Alternative Medicine in the United States: Cost Data. Integr. Med. 2008. Available online: https:/www.google.com.hk/url?sa=t\&rct=j\&q=\&esrc=s\&source=web\& $\mathrm{cd}=\& \mathrm{cad}=$ rja\&uact=8\&ved=2ahUKEwjM7MWT7JTqAhVB_KQKHVwGDa0QFjAAegQIBBAB\&url=htt p $\% 3 \mathrm{~A} \% 2 \mathrm{~F} \% 2 \mathrm{Fw} w w . o r i e n t a l m e d i c i n e . e d u \% 2 F d o w n l o a d s \% 2 F N H I S \_c o s t d a t a . p d f \& u s g=A O v V a w 0 d H s l s A$ 9VjzuftKRtrOBL_ (accessed on 1 July 2009).

36. Sun, X.D.; Liu, X.E.; Huang, D.S. Curcumin induces apoptosis of triple-negative breast cancer cells by inhibition of EGFR expression. Mol. Med. Rep. 2012, 6, 1267-1270. [CrossRef]

37. Nguyen, L.T.; Lee, Y.-H.; Sharma, A.R.; Park, J.-B.; Jagga, S.; Sharma, G.; Lee, S.-S.; Nam, J.-S. Quercetin induces apoptosis and cell cycle arrest in triple-negative breast cancer cells through modulation of Foxo3a activity. Korean J. Physiol. Pharmacol. 2017, 21, 205-213. [CrossRef]

38. Mileo, A.M.; Miccadei, S. Polyphenols as Modulator of Oxidative Stress in Cancer Disease: New Therapeutic Strategies. Oxid. Med. Cell. Longev. 2016, 2016, 17. [CrossRef]

39. Yedjou, C.G.; Tchounwou, P.B. In vitro assessment of oxidative stress and apoptotic mechanisms of garlic extract in the treatment of acute promyelocytic leukemia. J. Cancer Sci. Ther. 2012, 2012, 6. [CrossRef]

40. Podsedek, A. Natural antioxidants and antioxidant capacity of Brassica vegetables: A review. LWT-Food Sci. Technol. 2007, 40,1-11. [CrossRef]

41. Mei, F.; You, J.; Liu, B.; Zhang, M.; Liu, J.; Zhang, B.; Pei, F. LASS2/TMSG1 inhibits growth and invasion of breast cancer cell in vitro through regulation of vacuolar ATPase activity. Tumor Biol. 2015, 36, 2831-2844. [CrossRef]

42. Zhu, M.; Chang, Q.; Wong, L.K.; Chong, F.S.; Li, R.C. Triterpene antioxidants from Ganoderma lucidum. Phyther. Res. 1999, 13, 529-531. [CrossRef]

43. Forcados, G.E.; Chinyere, C.N.; Shu, M.L. Acalypha wilkesiana: Therapeutic and Toxic Potential. J. Med. Surg. Pathol. 2016, 1, 1000122. [CrossRef]

44. Forman, H.J.; Zhang, H.; Rinna, A. Glutathione: Overview of its protective roles, measurement, and biosynthesis. Mol. Asp. Med. 2009, 30,1-12. [CrossRef] [PubMed]

45. Friesen, C.; Kiess, Y.; Debatin, K.M. A critical role of glutathione in determining apoptosis sensitivity and resistance in leukemia cells. Cell Death Differ. 2004, 11, S73-S85. [CrossRef] [PubMed]

46. Sheweita, S.A.; Mashaly, S.; Newairy, A.A.; Abdou, H.M.; Eweda, S.M. Changes in oxidative stress and antioxidant enzyme activities in streptozotocin-induced diabetes mellitus in rats: Role of alhagi maurorum extracts. Oxid. Med. Cell. Longev. 2016, 2016, 8. [CrossRef] [PubMed] 
47. Wang, G.; Zhang, J.; Mizuno, T.; Zhuang, C.; Ito, H.; Mayuzumi, H.; Okamoto, H.; Li, J. Antitumor Active Polysaccharides from the Chinese Mushroom Songshan Lingzhi, the Fruiting Body of Ganoderma Tsugae. Biosci. Biotechnol. Biochem. 1993, 57, 894-900. [CrossRef]

48. Gao, L.-L.; Feng, L.; Yao, S.-T.; Jiao, P.; Qin, S.; Zhang, W.; Zhang, Y.-B.; Li, F.-R. Molecular mechanisms of celery seed extract induced apoptosis via $S$ phase cell cycle arrest in the BGC-823 human stomach cancer cell line. Asian Pac. J. Cancer Prev. 2011, 12, 2601-2606.

49. Watts, M.J.; Galpin, I.J.; Collin, H.A. The Effect of Growth Regulators, Light and Temperature on Flavour Production in Celery Tissue Cultures. New Phytol. 1984, 98, 583-591. [CrossRef]

50. Bunpo, P.; Kataoka, K.; Arimochi, H.; Nakayama, H.; Kuwahara, T.; Bando, Y.; Izumi, K.; Vinitketkumnuen, U.; Ohnishi, Y. Inhibitory effects of Centella asiatica on azoxymethane-induced aberrant crypt focus formation and carcinogenesis in the intestines of F344 rats. Food Chem. Toxicol. 2004, 42, 1987-1997. [CrossRef] [PubMed]

51. Wang, L.; Xu, J.; Zhao, C.; Zhao, L.; Feng, B. Antiproliferative, cell-cycle dysregulation effects of novel asiatic acid derivatives on human non-small cell lung cancer cells. Chem. Pharm. Bull. 2013, 61, 1015-1023. [CrossRef]

52. Sa, G.; Das, T. Anti cancer effects of curcumin: Cycle of life and death. Cell Div. 2008, 3, 14. [CrossRef]

53. Chen, H.-W.; Lee, J.-Y.; Huang, J.-Y.; Wang, C.-C.; Chen, W.J.; Su, S.-F.; Huang, C.-W.; Ho, C.-C.; Chen, J.J.; Tsai, M.-F.; et al. Curcumin inhibits lung cancer cell invasion and metastasis through the tumor suppressor HLJ1. Cancer Res. 2008, 68, 7428-7438. [CrossRef] [PubMed]

54. Ogungbe, I.V.; Erwin, W.R.; Setzer, W.N. Antileishmanial phytochemical phenolics: Molecular docking to potential protein targets. J. Mol. Graph. Model. 2014, 48, 105-117. [CrossRef] [PubMed]

55. Abugri, D.A.; Witola, W.H.; Jaynes, J.M.; Toufic, N. In vitro activity of Sorghum bicolor extracts, 3-deoxyanthocyanidins, against Toxoplasma gondii. Exp. Parasitol. 2016, 164, 12-19. [CrossRef]

56. Esterbauer, H.; Schaur, R.J.; Zollner, H. Chemistry and biochemistry of 4-hydroxynonenal, malonaldehyde and related aldehydes. Free Radic. Biol. Med. 1991, 11, 81-128. [CrossRef]

57. Janero, D.R. Malondialdehyde and thiobarbituric acid-reactivity as diagnostic indices of lipid peroxidation and peroxidative tissue injury. Free Radic. Biol. Med. 1990, 9, 515-540. [CrossRef]

58. Johansson, L.H.; Håkan Borg, L.A. A spectrophotometric method for determination of catalase activity in small tissue samples. Anal. Biochem. 1988, 174, 331-336. [CrossRef]

59. Forstrom, J.W.; Zakowski, J.J.; Tappel, A.L. Identification of the Catalytic Site of Rat Liver Glutathione Peroxidase as Selenocysteinet. Biochemistry 1978, 17, 2639-2644. [CrossRef]

60. Surh, Y.J. Anti-tumor promoting potential of selected spice ingredients with antioxidative and anti-inflammatory activities: A short review. Food Chem. Toxicol. 2002, 40, 1091-1097. [CrossRef]

61. Sznarkowska, A.; Kostecka, A.; Meller, K.; Bielawski, K.P. Inhibition of cancer antioxidant defense by natural compounds. Oncotarget 2017, 8, 15996-16016. [CrossRef] [PubMed]

62. Willcox, J.K.; Ash, S.L.; Catignani, G.L. Antioxidants and prevention of chronic disease. Crit. Rev. Food Sci. Nutr. 2004, 44, 275-295. [CrossRef] [PubMed]

(C) 2020 by the authors. Licensee MDPI, Basel, Switzerland. This article is an open access article distributed under the terms and conditions of the Creative Commons Attribution (CC BY) license (http://creativecommons.org/licenses/by/4.0/). 